\title{
RISK MANAGEMENT IN FACE OF PANDEMIA: A FEDERAL PUBLIC INSTITUTION OF HEALTH BEHAVIOR PERFOMED IN THE SARS- COV-2 VIRUS PANDEMIC
}

\author{
Maria das Graças Coelho Miguelote ${ }^{a}$, Josiane Dantas Viana Barbosa \\ aOswaldo Cruz Foundation, FIOCRUZ, Salvador, BA, Brazil; \\ graca.miguelote@fiocruz.br \\ bSENAI CIMATEC University Center, Salvador, BA, Brazil; josianedantas@fieb.org.br
}

\begin{abstract}
Risk management involves a collection of interconnected processes, such as prevention, mitigation, and response. Multiple types of researches have shown, until this time of the SARS-CoV-2 pandemic, that's possible to involve reactive, corrective, and prospective risk measures. This study aims to identify actions that observe, mitigate and, prevent risks, based on a descriptive review of risk management just ass actions to combat the pandemic. The results showed that there is an interconnection between risk management and activities developmented by Fiocruz. In the meantime, risk management is identified in Fiocruz's actions when it produces tests, organizes preventive measures and invests technologies for vaccine production, intending the population immunization to SARS-CoV-2.
\end{abstract}

Keywords: Covid-19; Risks; Measures; Pandemic.

\section{GESTÃO DE RISCOS FRENTE A PANDEMIA: COMPORTAMENTO DE UMA INSTITUIÇÃO PÚBLICA FEDERAL DE SAÚDE FRENTE A PANDEMIA DO VÍRUS SARS-CoV-2}

Resumo: Gestão de riscos abraça um agrupamento de processos que se interligam, como prevenção, mitigação e reposta. A pesquisa mostrou, nesse momento de pandemia pelo SARS-CoV-2, ser possível envolver medidas reativas, corretivas e prospectivas dos riscos. Este estudo tem como objetivo identificar ações que encarem, atenuem e previnam riscos, com base em uma revisão descritiva e documental sobre gestão de riscos e ações de enfrentamento à pandemia. Os resultados indicaram que existe uma interligação entre gestão de riscos e ações de enfrentamento elaboradas pela Fiocruz. Nesta base, gestão de riscos é identificada nas ações da Fiocruz quando esta produz testes, organiza medidas de prevenção e investe tecnologias para produção de vacina para imunização da população ao SARS-CoV-2.

Palavras-chave: Covid-19; Riscos; Medidas; Pandemia. 


\section{INTRODUCTION}

The new coronavirus pandemic (SARS-CoV-2), what caused the disease COVID-19, arrived in Brazil on February 25, 2020, when the Health Ministry announced the first case of the disease in a 61 years old man. Until April 22, 2020, the country had confirmed 45,757 cases of disease COVID-19 and 2,906 deaths, according to official data from the Department of Health. At the beginning, most of the notifications in Brazil were in São Paulo, which concentrated 15,914 confirmed cases and 1,134 deaths. The second state with the most cases was Rio de Janeiro, which presented 5,552 confirmations and 490 deaths in the first sixty days of the pandemic. All Brazilian states until this point already register cases and deaths by coronavirus. [1]

At March, 11, 2020 the World Health Organization - WHO establishes world corona virus pandemic. The SARS-CoV-2 virus provides to the world a group of new risks and challenges in health emergencies sector. That's require immediate responses from health organizations and departments around the world. [2]

As a health institution part of the Unified Health System of Brazil, Fiocruz works on several fronts to combat the pandemic. Fiocruz was the first Brazilian institution to develop in 40 days the tests RT-PCR protocol (reverse-transcriptase polymerase chain reaction) to detect the virus, even before any case confirmed in Brazil at that point. Few days after, Fiocruz provided 250,000 tests per week to public hospitals and health centers, which can be characterized as a corrective action to risks. [3]

In its trajectory, Fiocruz has been present at events of relevance in Brazilian public health, participating through at the VIII Health Conference, which is considered a milestone in the history of health conferences as well as the first open to society's participation. Your relevance is visible since the promulgation of 1988 Constitution that consider health an inalienable right of all citizens. Fiocruz also actively participated in the creation of Unified Health System of Brazil.

Risk management in this current context of SARS-CoV-2 is indispensable with the goal to capture elements of learning to public health emergencies in order to empower the contingencies of preparation, readiness and immediate responses to the Unified Health System (SUS) in the panorama of health emergencies and possible pandemics.

According SILVA [4], in addition to the immediate and basic measures in the management of health emergencies, which focuses on reactive and corrective risk management with interventions to reduce the current risk, it's essential that the measures are linked to prospective risk management, including a set of actions to strengthen practices to reduce vulnerabilities, improve response capacities and stimulate prevention ways from news risks relative to health emergencies.

Reactive risk actions as immediate responses such as measures to prevent dissemination composing medium and long-term actions, guide us to link risk management to public governance in face the pandemic. Thus, reactive and corrective management to reduce risks must be linked to a prospective vision of risks for reducing vulnerabilities and strengthening the capacity of responses to the health sector. [5]

Studies by Agrela [6] and Fioratti [7] showed the Coronavirus pandemic started in the Asian region of the city of Wuhan with the bats, snakes, and camels being transmitted as hosts to humans as zoonosis by infected animals, causing mild and severe respiratory infections. 
The virus received this nomenclature because of the appearance of a crown. The coronavirus represents a group of viruses that can affect animals and humans causing moderate symptoms of sore throat, runny nose, cough, headache typical of a flu or cold. However, some coronavirus can develop more severe respiratory pathologies causing even death. [7]

Referred as a new coronavirus, the SARS-COV-2 it's a mutation of the corona, which induced Severe Acute Respiratory Syndrome (SARS) at ASIA and Middle East Respiratory Syndrome (MERS) [8]

Similar virus to SARS-CoV-2 in the las decade was highlighted in 2002 China Pandemic which affected 8.000 (eight thousands) people with a high level of death around 9,6\% and affected 2.000 (two thousands) people in the 2012 Middle East Respiratory Syndrome with the level of death around 35\% mainly in Saudi Arabia and neighboring countries. $[9,10]$

The objective of this work was to map the interconnection between reactive, corrective and prospective risk management with actions carried out by Fiocruz.

\section{METHODOLOGY}

Based on descriptive and documentary methodology it was possible to elaborate an analysis of the behavior of a federal public institution - Fiocruz in face of one of the biggest challenges in the history of humankind. It was challenging at the same time was a rich environment to identify immediate health responses to a desire. Considering risk management as a preponderant action to deal with the pandemic, like the manufacture of quick check tests for COVID-19 disease before the first case was confirmed in Brazil followed by the start of production of a vaccine for immunization against contamination by SARS -CoV-2. These measures lead us to believe that only a recognized institution with a largest trajectory as Fiocruz can provide several ways to collaborate and face the Pandemic with the Unified Health System (SUS). The challenge was create an approach in front of this so brand new event.

The methodology was based in to examine papers, journalistic comments, Fiocruz periodicals were also reviewed that concern the theme, although relatively new, it was possible to extract opinions and establish a introductory parallel between risk management and emergency health actions.

After reading articles, it was possible to identify earlier and efficient actions to deal with the pandemic, in contrast, we observed mismatched government actions such as the lack of coherence and responsibility in the positioning of internal federal government agents when they expressed themselves in interviews and notes considering the serious moment of crisis health that the country and the world faces as if the pandemic were a "little cold" or a virosis passenger without complications leading to hospital admissions and death. Despite this gap of sobriety in value the crisis as relevant as it is, reading articles and publications we were able to observe the independent action of each state and municipal governments to face the pandemic with dedication and responsibility intending to protect public chaos and preserve the population's health. Interact this sources was a valuable tool construct the principal argumentative and narrative to write this article.

After reading different positions in the face of the pandemic, it was possible to observe that measure of risk management was a relevant topic. From the institutional 
sources and informations was possible to verify Fiocruz's actions in face of the pandemic with reactive, corrective, and prospective risk management actions, as well as the importance of integrating these with the measure of governance.

\subsection{Informations Collected}

Fiocruz was the first Brazilian public institution to develop the RT-PCR tests protocols in 40 days to detect the virus, even before any case was confirmed in Brazil. It was starting when it was necessary to provide 250,000 tests per week to public hospitals through SUS. The kits were developed by the Institute of Technology in Immunobiologicals (Bio-Manguinhos / Fiocruz). [3]. The following figure is a demonstration of these kits.

Figure 1. Capacity of production

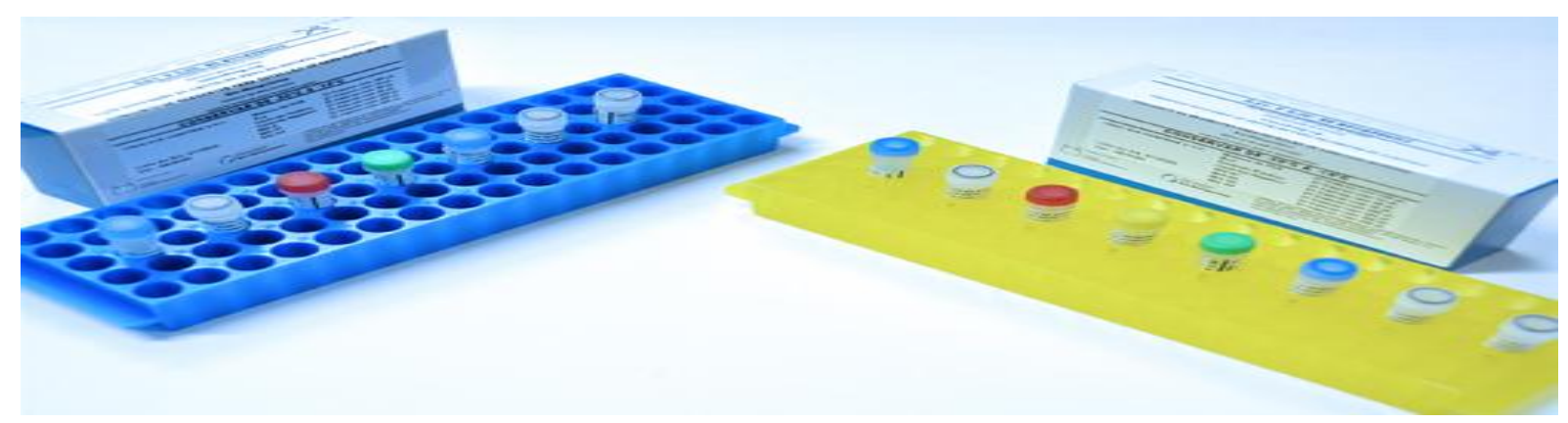

Source: portal.fiocruz.br

Fiocruz has the capacity to produce around 20 thousand tests per week and the production speed will continue according to the demand of the Ministry of Health (Photo by Bernardo Portella)

In light of the impossibility to eliminate the threat such as the Sars-Cov-2 virus, some measures to prevent the spread of the virus became necessary and were adopted and disseminated by the institution, such as the edition of the FIOCRUZ Contingency Plan, in March 2020. [11]

Figure 2. Fiocruz Contigency Plan

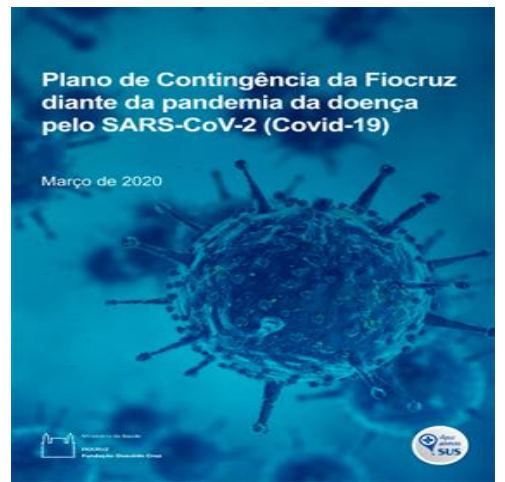

Source: portal.fiocruz.br

\subsection{Selected Sample}

This new scenario of risks which the disease entitled Covid-19 provides is a compromising atmosphere in terms of immediate responses to the risks of new public health emergencies and to the medium and long terms actions. That challenge lead us to link risk management to the public governance of facing the pandemic. [5] 
Reactive and corrective management to reduce risks must be integrated with a prospective view of risks to reduce vulnerabilities and strengthen the capacity of responses to the health sector. The following table illustrates this integration.

Figure 3. Risk Management Map

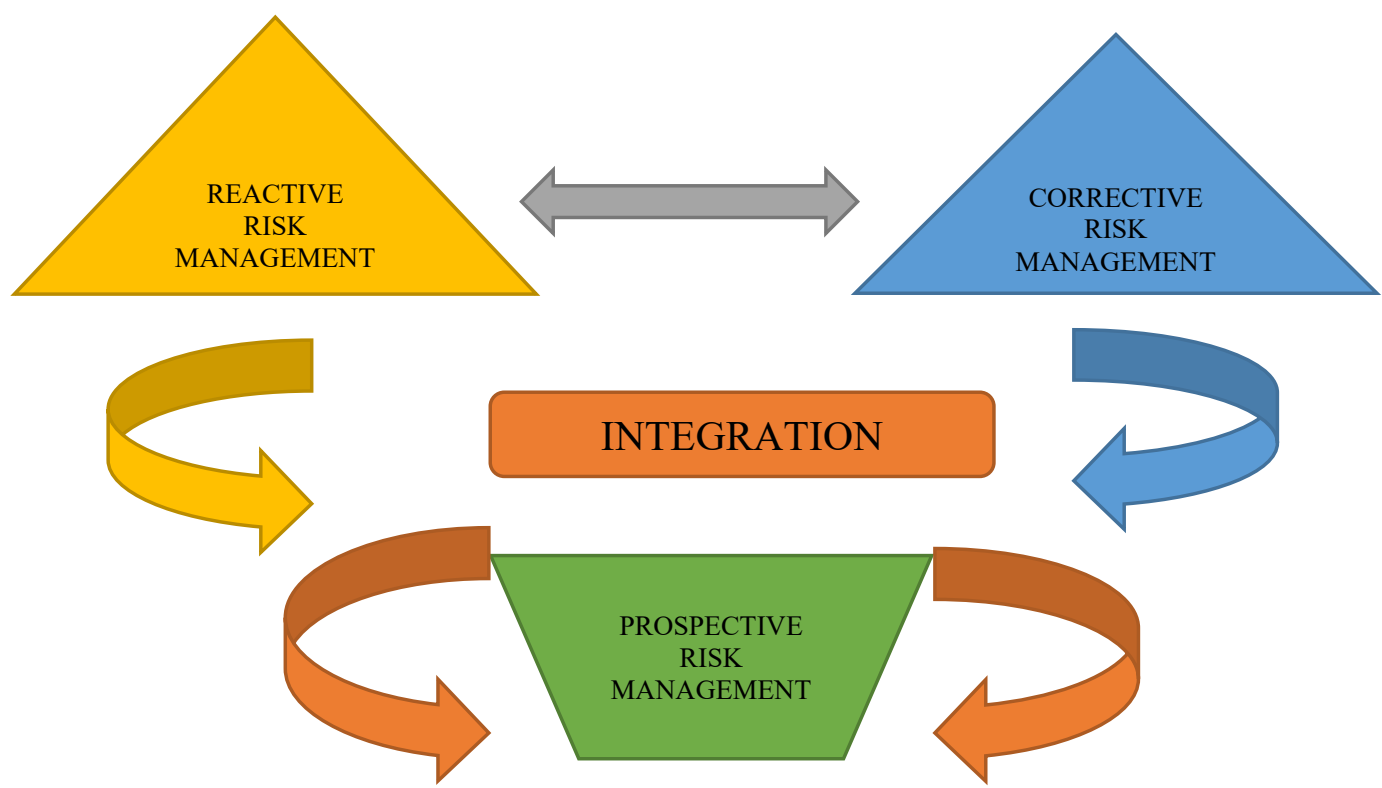

Source: elaborated by the authors

The strengthening of governance occurs through the interconnection between the health sector (SUS) and segments of society. Without this linkage, we can't have appropriate responses to the risks facing the pandemic. It's essential the vertical and horizontal coordination between federal, state, municipal, and representatives of civil society in the battle against emergencies.

Unfortunately in Brazil, there is a mismatch of guidelines and preventive measures between the federal, state and municipal governments when recommending protection measures without an alignment between these three spheres of government. This mismatch of actions allowed each representative of the federative units to take different attitudes towards risk management, reducing and preventing coordinated risk management to face the pandemic.

This topic was strongly relevant to comprehension of Federal Supreme Court (STF) decision in Abril, 15, 2020 when the Minister Alexandre de Moraes established that state and city government has the qualification to determine restrictive measures to respond the SARS-CoV-2 crises. According to this decision, municipal governments could complement the normative about this subject. [12]

The table below shows some measures taken by states and municipalities.

Table 1. COVID-19 crises governments measures

\begin{tabular}{|l|l|}
\hline \multicolumn{1}{|c|}{ CATEGORIES OF MEASURE } & DESCRIPTIONS OF MEASURES \\
\hline Cordination & $\begin{array}{l}\text { Multisectoral measures involving governments sector, not- } \\
\text { governments sector and others segments of the Society. }\end{array}$ \\
\hline
\end{tabular}




\begin{tabular}{|l|l|}
\hline Social distancing & $\begin{array}{l}\text { Measures taken to reduce contact between people intending } \\
\text { to reduce transmission and not overburden the public health } \\
\text { system. }\end{array}$ \\
\hline Information and Communication & $\begin{array}{l}\text { Measures which guarantee the right of information and } \\
\text { communication to the population. Information needed to assist } \\
\text { in decision making. }\end{array}$ \\
\hline Border control and boundary & $\begin{array}{l}\text { Measures taken to reduce the possibility of transmission } \\
\text { between municipalities and states. }\end{array}$ \\
\hline Control of market products & Market price control measures for products \\
\hline Public security & Public order guarantee measures \\
\hline
\end{tabular}

Source: fiocruz portal, adapted

Autonomous measures taken by state and municipal governments to contain and spread the pandemic, were essential to protect society and not overburden the health system.

\subsection{Identification}

Risk management is characterized by a complex process, driven by institutional structures, which aims at formulating and implementing policies, strategies and actions to intervene in conditions of vulnerability and to act on the threats that present attitudes that have been taken throughout the pandemic state that Fiocruz has been adopting. The attitudes shown in the table below stand out.

Figure 4. Fiocruz Actions

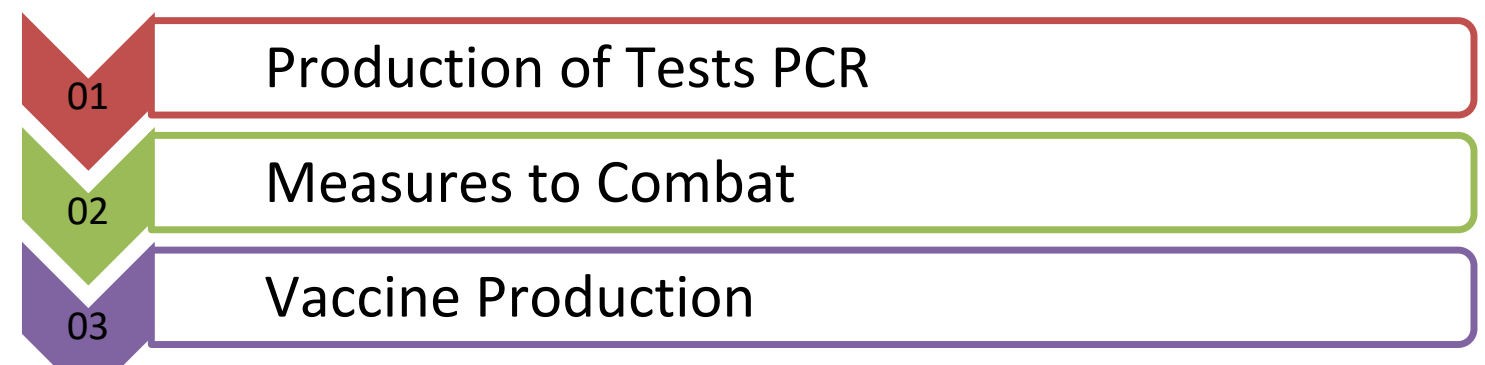

Source: elaborated by the authors

This tripod of actions is strictly related to corrective, reactive and prospective risk management actions.

\section{RESULTS AND DISCUSSION}

The integration between federative government and health sectors is extremely important for a good result in the complex risk management process, to achieve coherence in the development of measures, as well as for the production of immediate responses and mitigation of current risks and also for recovery part, considering account the prevention of future risks.

Since created in 1988, the Brazilian Unified Health System (SUS) has been present in the lives of brazilians playing a fundamental role in public health. The integrated action of institutions, government officials and society will provide us with a sooner return to a previously forgotten normality. As a learning process the control measures taken by state and municipal governments, mainly social isolation, in an optimistic perspective, made the population revise their concepts of solidarity, empathy 
that will stimulate new values and habits, providing a return to the social development and growth. As soon as possible after all, this is largely due to the capacity and behavior of SUS despite the restrictions of the federal government in recent months, it provides free access to the Brazilian population for minimum treatments thanks to health institution like Fiocruz.

\section{FINAL CONSIDERATIONS}

After this study, it is was possible to observe the actions developed by Fiocruz were very important for Brasil to predict efforts at combating the spread of virus SARS-CoV-2. All these actions have a strong relationship with measures Ministry of Health, even before the confirmation of the first case of disease COVID-19 in the country. And now more recently, we initiate the development of a vaccine for immunization against SARS-CoV-2 in partnership with Oxford University of England.

The integration of the development of technologies such as virus detection test and vaccine production linked to measures to contain the disease are preponderant factors to the control of current pandemic, and can be nominated as a risk prevention structure in a prospective view that other pandemics may will happen. New studies will emerge from the current pandemic experience.

In fact, risk management is closely related to actions to face the pandemic taken by Fiocruz as an agency belonging to the Ministry of Health.

As described before, the objective of this paper was mapping the interconnection between reactive, corrective and prospective risk management with actions taken by Fiocruz such as the production of virus detection test, facing measures and investment in vaccine production.

The study was limited to observe the behavior of the disastrous actions of the federal government, the reaction of states and municipalities to contain the spread of the virus and also about the possible collapse of the health sector and the actions of a federal public health institution in the face of the challenges the pandemic imposes on Brazil.

It's important to stand out that risk management is closely linked to the prevention and containment of the SARS-CoV-2 dissemination. In conclusion, it's observed that the country can count on to the capacity of the public health institutions, such as Fiocruz, with immediate responses to the pandemic which affects the country.

\section{REFERENCES}

${ }^{1}$ BRAZIL. Ministry of Health. Epidemiological Bulletin $n^{\circ} 13$ - Public Health Emergency Operations Center for Human Coronavirus Infection

(COE-nCoV). Available in: https://portalarquivos.saude.gov.br/images/pdf/2020/April/21/BE13---Boletim-doCOE.pdf.

${ }^{2} \mathrm{WHO}$. Director-General's opening remarks at the media briefing on COVID-19 11 March 2020. Available in https://www.who.int/dg/speeches/detail/who-directorgeneral-s-opening-remarks-at-the-media-briefing-on-covid-19-11-march-2020. 
${ }^{3}$ Brazil 2020. Fiocruz 120 years. Available in: https://www.canalsaude.fiocruz.br/canal/videoAberto/fiocruz-120-anos-enfrentandoepidemias-sdc-0505.

${ }^{4}$ SILVA, Isadora Vida de Mefano et al. Risk management and governance in the COVID-19 pandemic in Brazil: analysis of state decrees in the first month: technical report and executive summary. 2020

${ }^{5}$ CEPEDES. Risk management and governance in the covid-19 pandemic in Brazil, 2020.

${ }^{6}$ AGRELA, L. Individual infected with coronavirus can infect up to five people. Revista Exame, 11/03/2020. Available in: www.exame.abril.com.br.

${ }^{7}$ FIORATTI, C. Yes, the coronavirus came from nature - not from a laborator. Revista Super Interessante, 20/03/2020. Available in: www.super.abril.com.br.

${ }^{8} \mathrm{LUIGI}, \mathrm{R}$; SENHORAS, E. M. The new coronavirus and the importance of international organizations. Nexo Jornal, 17/03/2020. Available in: www.nejornal.com.br.

9SENHORAS, E. M. New coronavirus and its world economic impacts. Conjuncture Bulletin, vol. 1, n. 2, 2020.

${ }^{10}$ FIRMIDA, M. Coronavirus: What virus is this? Rio de Janeiro: Infection Commission of SOPTERJ, 2020. Available in: www.sopterj.com.br.

${ }^{11}$ BRASIL. Ministry of Health. Fiocruz's Contingency Plan in the face of the disease pandemic by SARS-Cov-2 (Covid-19). v.1. 2020. Available in: <https://portal.fiocruz.br/sites/portal.fiocruz.br/files/documentos/plano_de_contingenci a_corona_final_2020-03-13_v1.pdf.

${ }^{12}$ BRASIL 2020. Provisional Measure 926/2020. Available in: http://www.stf.jus.br/portal/cms/verNoticiaDetalhe. $a s p ?$ idConteudo=441447. 